\title{
Minimal Change Disease and Bilateral Non- arteritic Ischemic Optic Neuropathy in a Patient with Pleural Mesothelioma
}

\author{
Plevral Mezotelyomalı Bir Hastada Bilateral Non-arteritik İskemik Optik Nöro- \\ pati ve Minimal Değişiklik Hastalığı
}

Senyo Tagboto

\begin{abstract}
Malignant mesothelioma typically presents with slowly progressive dyspnea and chest pain. Extra-thoracic symptoms and paraneoplastic presentations are very rare. The association of this malignancy with glomerular disorders has been only rarely reported in the literature. The present report describes the case of a 65-year-old man with a remote occupational exposure to asbestos more than 26 years prior who presented with a month's history of slowly progressive visual loss, minimal weight loss, and pedal edema. Assessments by several ophthalmologists concluded that he had developed non-arteritic ischemic optic neuropathy. Further nephrological work-up demonstrated that he had developed nephrotic syndrome due to minimal change disease, which was confirmed with a renal biopsy. His clinical symptoms rapidly improved with steroid treatment. The nephrotic syndrome went into clinical remission, his progressive visual loss improved, and there was no further weight loss. The initial chest $X$-ray performed when he first presented was reported as showing only chronic changes. He reported the symptoms of shortness of breath and chest pain 8 months later and was found to have a large right pleural effusion. Further investigation revealed pleural mesothelioma.
\end{abstract}

Key words: Malignant mesothelioma, minimal change disease, nephrotic syndrome, non-arteritic ischaemic optic neuropathy.

\section{Özet}

Malign mezotelyoma tipik olarak yavaş ilerleyen dispne ve göğüs ağrısı ile kendini göstermektedir. Toraks dışı semptomlar ve paraneoplastik tablolar çok nadirdir. Bu maliginite ile glomerüler hastalık birlikteliği literatürde nadiren bildirilmiştir. Bu olgu sunumunda, 26 yıl önce mesleksel asbest maruziyeti olan son bir aydır yavaş ilerleyen görme kaybı, hafif kilo kaybı ve ayaklarda ödem yakınmaları olan 65 yaşında erkek hasta sunulmuştur. Göz hastalıkları uzmanları tarafından non-arteritik iskemik optik nöropati geliştiği belirlendi. İleri nefrolojik incelemelerde renal biyopsi ile doğrulanan minimal değişiklik hastalığına bağlı nefrotik sendrom olduğu gösterildi. Steroid tedavisi ile klinik semptomlar hızla düzeldi. Nefrotik sendrom ve ilerleyici görme kaybı klinik olarak remisyona girdi ve kilo kaybı düzeldi. Başlangıç akciğer grafisi yalnızca kronik değişiklikler gösteriyordu. Sekiz ay sonra nefes darlığı ve göğüs ağrısı semptomları ortaya çıkłı ve sağ da yoğun plevral sıvı saptandı. Illeri incelemelerde plevral mezotelyoma tespit edildi.

Anahtar Sözcükler: Malign mezotelyoma, minimal değişiklik hastalığı, nefrotik sendrom, non-arteritik iskemik optik nöropati.

Yarmouth Regional Hospital, Yarmouth, Canada; University of Health and Allied Sciences, Ho, Ghana

Yarmouth Bölge Hastanesi, Yarmouth, Kanada; Sağlık ve Yardımcı Bilimler Üniversitesi, Ho Gana Submitted (Başvuru tarihi): 11.04.2018 Accepted (Kabul tarihi): 24.07.2018

Correspondence (iletişim): Senyo Tagboto, Yarmouth Regional Hospital, Yarmouth, Canada; University of Health and Allied Sciences, Ho, Ghana

e-mail: senyo2@hotmail.com 
Malignant pleural mesothelioma (MPM) is an uncommon, but highly aggressive, tumor of the mesothelial lining of the thoracic cavity. Malignancy typically develops after a long latency period following asbestos exposure (2). Most patients with MPM present with the gradual onset of nonspecific symptoms, such as chest pain, dyspnea, cough, hoarseness, night sweats, or dysphagia. The association with paraneoplastic manifestations like renal glomerular disease has rarely been reported, and to the best of our knowledge, there are no reports of non-arteritic ischemic optic neuropathy associated with MPM.

\section{CASE}

A 65-year-old man was seen in the emergency room and reported a month's history of progressive, bilateral visual loss affecting his right eye more than his left. On direct questioning, he denied the occurrence of headaches, nausea, vomiting, neck stiffness, and diplopia, as well as chest pain and shortness of breath. He did not have a cough, nor was he bringing up sputum. Further questioning revealed some weight loss of 1 or 2 kilograms in the preceding month.

The patient was married and drank 5 to 6 glasses of wine a week. He had given up smoking 6 years earlier. He had previously been exposed to asbestos while working in the shipbuilding industry between 1972 and 1980.

His past medical history included benign prostatic hypertrophy and hypertension, for which he was taking tamsulosin, dutasteride, and trandolapril.

He was examined by the ophthalmology team who documented that his pupils were equal and responsive to light. Intraocular pressure measurements were normal: $17 \mathrm{mmHg}$ in the right eye and $15 \mathrm{mmHg}$ in the left. Fundoscopy showed normal anterior segments and bilateral disc edema. Goldmann visual field testing demonstrated severe constriction of both fields with large, fairly symmetrical, central scotomas. The ophthalmology team diagnosed bilateral non-arteritic ischemic optic neuropathy. The rest of his physical examination was unremarkable, with the exception of moderate pitting edema, which the patient had noticed in the preceding 2 to 3 weeks.

Neuroimaging revealed a cavernous hemangioma in the right orbit. The results of cerebrospinal fluid testing for protein and glucose were within normal limits, and cerebrospinal fluid cytology contained no atypical cells. Genetic testing for Leber's hereditary optic neuropathy was negative.

Additional investigation indicated that he had developed nephrotic syndrome. A 24-hour urine collection demon- strated significant proteinuria (10.12 g/day). Additionally, he had a low plasma albumin level of $19 \mathrm{~g} / \mathrm{L}$ and an elevated serum cholesterol level of $8.4 \mathrm{mmol} / \mathrm{L}$. A full blood count was within normal limits, with a hemoglobin level of $150 \mathrm{~g} / \mathrm{L}$. His erythrocyte sedimentation rate was measured at $80 \mathrm{~mm} /$ hour and his C-reactive protein level was $1 \mathrm{mg} / \mathrm{L}$. Electrolyte levels were within normal limits and the plasma creatinine value recorded was $94 \mu \mathrm{mol} / \mathrm{L}$. An initial chest $X$-ray illustrated chronic scarring at the base of the left lung (Figure 1).

The results of investigation of immunoglobulin levels, serum protein electrophoresis, peripheral blood flow cytometric immunophenotyping, fecal occult blood in the stool, a coagulation screen, renal function, electrolytes, liver function, calcium and phosphate levels, thyroid function, antinuclear antibodies, serum complement components C3 and C4, cryoglobulins and a vasculitis screen, serum levels of Ca 19-9, carcinoembryonic antigen, and angiotensin-converting enzyme, hepatitis B and $C$ and HIV screening, and a temporal artery biopsy were all normal.

A renal ultrasound scan showed 2 normal-sized and nonobstructed kidneys with preserved corticomedullary differentiation. A subsequent renal biopsy demonstrated 13 glomeruli that looked normal on light microscopy with 2 that were globally sclerosed. Immunofluorescence was negative. Electron microscopy showed extensive foot process effacement with no evidence of immune deposits. A diagnosis of nephrotic syndrome secondary to minimal change disease (MCD) was made and treatment of oral prednisone $60 \mathrm{mg}$ daily was initiated. Two months later, his proteinuria had virtually resolved, with an albumin creatinine ratio of $4.37 \mathrm{mg} / \mathrm{mmol}$. The nephrotic syndrome also receded and remained in clinical remission. Moreover, his optic disc edema resolved and his vision improved while on steroids. Over the next couple of months, he reported feeling very well and did not lose weight.

Eight months after his initial presentation, he returned to the hospital with a complaint of dyspnea. A chest X-ray revealed that he had developed a large, right-sided, pleural effusion (Figure 2). A computed tomography (CT) scan of his chest showed scattered micronodularity of the left lung, mediastinal lymphadenopathy, and bilateral effusions, which were greater on the right side. Bronchoscopy results were unremarkable. A video-assisted pleural biopsy demonstrated tumor cells with a biphasic appearance and glandular and sarcomatoid morphology consistent with epithelioid and sarcomatoid malignant meso- 
thelioma. A positron emission tomography scan revealed moderate degrees of enhanced metabolic activity in both pleural areas, consistent with bilateral mesothelioma (Figure 3.)

\section{DISCUSSION}

Malignant pleural mesothelioma (MPM) is a highly aggressive tumor of the mesothelial lining of the thoracic cavity, associated with prior asbestos exposure and a poor survival rate (1). Globally, there are estimated to be 107,000 deaths annually from the disease. Inhaled asbestos fibers can become trapped in the lungs and migrate to the pleural lining, where they may trigger genetic changes in the mesothelial cells. Malignancy typically develops after a long latency period following asbestos exposure (2).

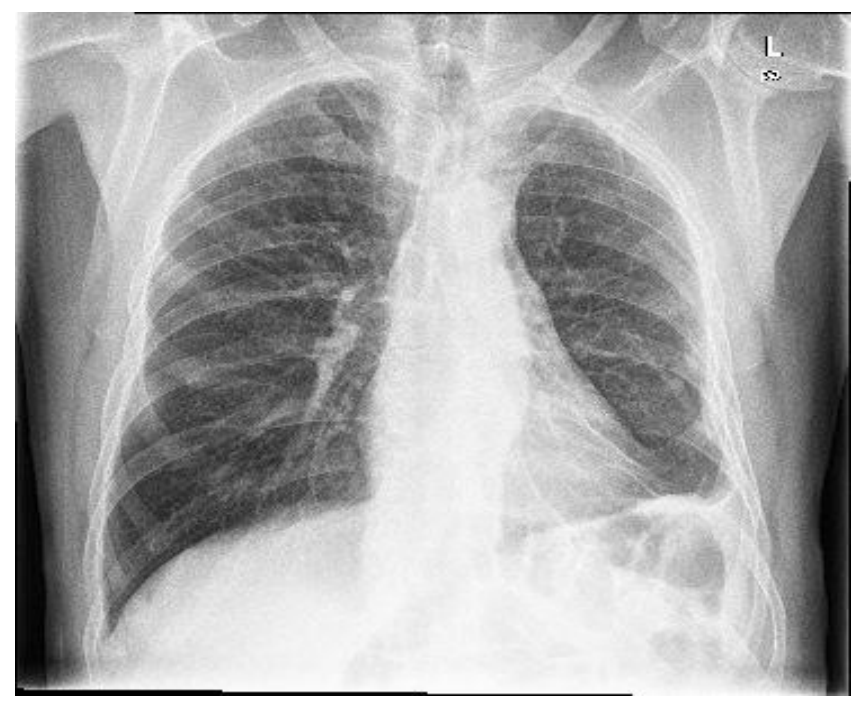

Figure 1: CXR April 2017

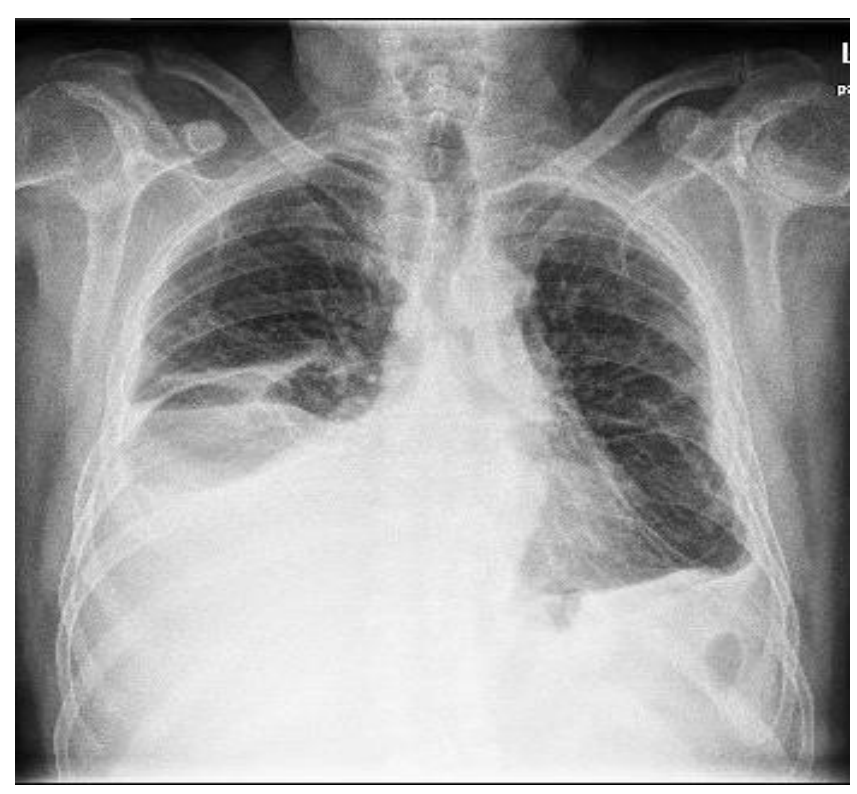

Figure 2: CXR December 2017, Right pleural effusion
The diagnosis of MPM currently requires pathological examination and immunohistochemical analyses that are supplemented with radiological examination, such as chest $\mathrm{X}$-rays and $\mathrm{CT}$ scans. Pathological confirmation can either be achieved by cytological examination of the pleural fluid, or more commonly, via an invasive surgical biopsy (3). Biomarkers, such as soluble mesothelin, osteopontin, and fibulin-3, have been investigated for their diagnostic potential in MPM. However, these do not have sufficient sensitivity and specificity to be stand-alone markers and require additional validation studies (4).

The treatment of MPM is challenging. Most cases are diagnosed at an advanced stage and are treated with systemic chemotherapy. Combination chemotherapy with cisplatin or carboplatin and pemetrexed is the standard treatment regimen, but despite this therapy, the median overall survival is only approximately 12 months $(5,6,7)$. Additional treatment modalities include supportive care for advanced disease and aggressive surgery-based multimodality regimens for fit patients with limited disease (8). The association between neoplasia and renal glomerular disease has been reported in the literature for over 30 years. The most commonly described lesion is membranous glomerulopathy, and $5 \%$ to $10 \%$ of cases are associated with underlying malignancy. Substantially less commonly, renal amyloidosis, mesangiocapillary glomerulonephritis, renal vasculitis, and minimal change disease may also be associated with neoplastic disease (9).

Membranous nephropathy is thought to arise as a consequence of the deposition of tumor antigens and antitumor antibodies in the glomerulus, causing an immune complex-type of glomerular injury. Additionally, the elaboration of a vascular permeability factor, cytokines, and chemokines by tumor cells may play a role in the development of the disease (2).

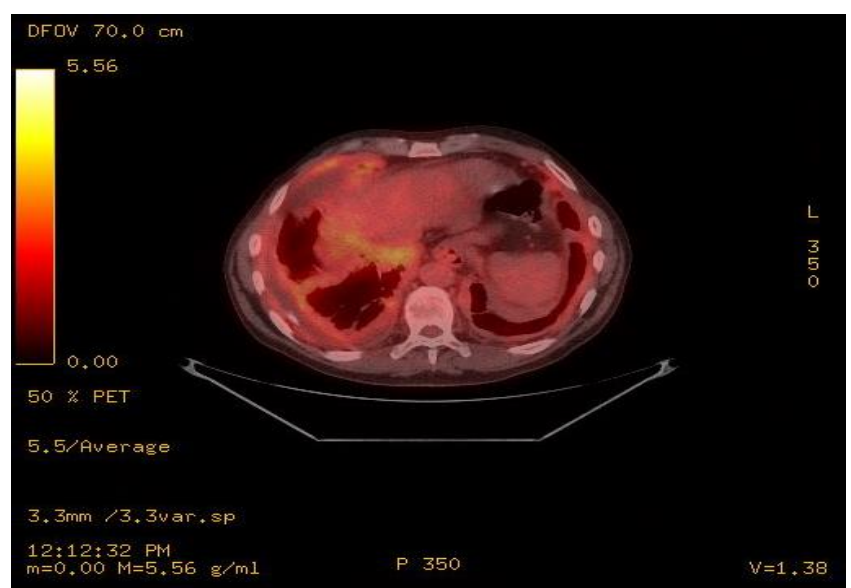

Figure 3: PET scan showing moderate degrees of enhanced metabolic activity in both pleural areas 
In the context of pleural mesothelioma, the association with renal glomerular disease has been rarely reported. There are only 10 cases of nephrotic syndrome associated with mesothelioma in the literature to date $(2-11)$. These have been previously described, compared, and presented in tabular form, and have been associated with poor survival (3). The majority of these cases have demonstrated minimal change disease on kidney biopsy $(2,4,8,9)$. There has only been 1 report of MPM associated with mesangial proliferative glomerulonephritis (5) and 2 associated with membranous nephropathy $(7,11)$. In 1 of the patients with membranous nephropathy, treatment of nephrotic syndrome with prednisolone and cyclophosphamide was ineffective, while subsequent treatment of the pleural tumor with doxorubicin hydrochloride and dacarbazine improved the patient's nephrotic syndrome (7).

Although ischemia and infarction have been reported in mesothelioma-associated glomerular disease $(2,12,13)$, and with nephrotic syndrome in general, there are no known specific reports in the medical literature of nonarteritic ischemic optic neuropathy associated with MPM, as seen our patient. Femoral artery thrombosis (13) and mesenteric thrombosis (2) have been reported. The latter was in a patient with minimal change nephropathy.

In summary, this was a case of progressive visual deterioration due to bilateral non-arteritic ischemic optic neuropathy and steroid-responsive minimal change disease, associated with pleural mesothelioma.

\section{CONFLICTS OF INTEREST}

None declared.

\section{AUTHOR CONTRIBUTIONS}

Concept - S.T.; Planning and Design - S.T.; Supervision S.T.; Funding - S.T.; Materials - S.T.; Data Collection and/or Processing - S.T.; Analysis and/or Interpretation S.T.; Literature Review - S.T.; Writing - S.T.; Critical Review - S.T.

\section{YAZAR KATKILARI}

Fikir - S.T.; Tasarım ve Dizayn - S.T.; Denetleme - S.T.; Kaynaklar - S.T.; Malzemeler - S.T.; Veri Toplama ve/veya İşleme - S.T.; Analiz ve/veya Yorum - S.T.; Literatür Taraması - S.T.; Yazıyı Yazan - S.T.; Eleştirel İnceleme - S.T.

\section{REFERENCES}

1. Robinson BW, Lake RA. Advances in malignant mesothelioma. N Engl J Med 2005; 353:1591-603. [CrossRef]

2. Bianchi C, Giarelli L, Grandi G, Brollo A, Ramani L, Zuch C. Latency periods in asbestos-related mesothelioma of the pleura. Eur J Cancer Prev 1997; 62:162-6.

3. Blyth KG, Murphy DJ. Progress and challenges in mesothelioma: from bench to bedside. Respir Med 2018; 134:31-41. [CrossRef]

4. Sun $H H$, Vaynblat A, Pass HI. Diagnosis and prognosisreview of biomarkers for mesothelioma. Ann Transl Med 2017; 5:244. [CrossRef]

5. Vogelzang NJ, Rusthoven JJ, Symanowski J, Denham C, Kaukel E, Ruffie $P$, et al. Phase III study of pemetrexed in combination with cisplatin versus cisplatin alone in patients with malignant pleural mesothelioma. J Clin Oncol 2003; $21: 2636-44$. [CrossRef]

6. Zalcman G, Mazieres J, Margery J, Greillier L, AudigierValette C, Moro-Sibilot D, et al. Bevacizumab for newly diagnosed pleural mesothelioma in the Mesothelioma Avastin Cisplatin Pemetrexed Study (MAPS): a randomised, controlled, open-label, phase 3 trial. Lancet 2016; 387:1405-14. [CrossRef]

7. van Zandwijk N, Clarke C, Henderson D, Musk AW, Fong K, Nowak A, et al. Guidelines for the diagnosis and treatment of malignant pleural mesothelioma. J Thorac Dis 2013; 5:E254-E307. [CrossRef]

8. Wolf AS, Daniel J, Sugarbaker DJ. Surgical techniques for multimodality treatment of malignant pleural mesothelioma: extrapleural pneumonectomy and pleurectomy/decortication. Semin Thorac Cardiovasc Surg 2009; 212:132-48. [CrossRef]

9. Ahmed M, Solangi K, Abbi R, Adler S. Nephrotic syndrome, renal failure, and renal malignancy: an unusual tumor associated glomerulonephritis. J Am Soc Nephrol 1997; 8:848-52.

10. Farmer CK, Goldsmith DJ. Nephrotic syndrome and mesenteric infarction secondary to metastatic mesothelioma. Postgrad Med J 2001; 77:333-4. [CrossRef]

11. Pu X, Dou Y, Liu D, Lu S, Quan S, Zhang X, Ma S, Zhao $Z$. Membranous nephropathy associated with malignant pleural mesothelioma in an adult patient: A case report. Mol Clin Oncol 2016; 5:407-10. [CrossRef]

12. Schroeter NJ, Rushing DA, Parker JP, Beltaos E. Minimalchange nephrotic syndrome associated with malignant mesothelioma. Arch Intern Med 1986; 146:1834-6. [CrossRef] 
13. Tanaka S, Oda H, Satta H, Takizawa T, Tochikubo O, Takagi $N$, et al. Nephrotic syndrome associated with ma- lignant mesothelioma. Nephron 1994; 67:510-1. [CrossRef] 